\title{
Stimulation Programme for Development of Cognitive Functions of Pupils From Marginalized Romany Communities in Slovakia
}

\author{
Bibiána Hlebová ${ }^{1}$ \\ ${ }^{1}$ Department of Special Education, Faculty of Education, University of Prešov in Prešov, Slovak Republic \\ Correspondence: Bibiána Hlebová, Faculty of Education, University of Prešov in Prešov. 17. Novembra 15, 080 \\ 01 Prešov, Slovak Republic.
}

Received: February 28, 2018

Accepted: April 6, 2018

Online Published: April 11, 2018

doi:10.20849/aes.v3i2.360

URL: https://doi.org/10.20849/aes.v3i2.360

\begin{abstract}
Subject of the study is the issue of effectiveness improvement within the education of socially disadvantaged pupils originating from marginalized Romany communities in younger school age in Slovakia through the stimulation of deficit cognitive functions, in the process of development of their communicative and reading competence. Main objective of the paper is presentation of stimulation programme proposal for development of cognitive functions (sorting, sequential auditory memory, short-term visual memory, addition of sequential patterns, perspective taking, and verbal planning) based on the methodology of dynamic testing of cognitive functions according to diagnostic measure ACFS (Application of Cognitive Functions Scale, Czech version, Lidz, Jepsen, Krejčová, 2014), for work with the adaption of Romany literary text (folk-tale) Children of the Sun from D. Hivešová-Šilanová. Children protagonist from socially disadvantaged backgrounds - Roma boy Lavutaris very sensitively perceives social differences in the intentions of own, minority society, as well as in their co-existence with the major society, and thus the implementation of cognitive stimulation programme takes on significance not only in the process of communicative and reading competence of socially disadvantaged pupils in younger school age, but within the multicultural and emotional education of all the pupils in terms of school inclusion in Slovakia as well.
\end{abstract}

Keywords: socially disadvantaged pupil, pupil from marginalized Romany community, cognitive functions, stimulation programme, communicative competence, reading competence, school inclusion

\section{Introduction}

Recently comes to the forth of many professionals in the field of education and cognitive psychology the issue of effectiveness improvement of education of pupils originated from socially disadvantaged backgrounds from marginalized Romany communities (very often with associated intellectual disabilities) in Slovakia, in the context of development of deficits in their cognitive functions in preschool and younger school age. They are children/pupils belonging to minority group of maladjusted Roma, labelled with social exclusion, poverty, psychological and cultural deprivation, and as a result these children lag behind their peers from the major society in psychological, mental and emotional processes, as well as in the mastering of literary Slovak language (their mother tongue is Romany), what causes problems in school when acquiring communicative and reading competence in Slovak language. According to the school legislation in force in Slovakia, these pupils, due to their social disadvantage and intellectual disabilities) belong to a group of students with special educational needs, whose education takes place in special elementary schools with educational variant A, or in elementary schools in special classrooms, or in individual school integration/inclusion. It follows that the pupils in a process of education require special individual educational and interventional approaches, where belong, also in the paper presented, proposal for drafting and implementation of stimulation programme focused on the development of deficits in their cognitive functions in the context of improvement of communicative and reading competence level at a school.

Validity of processing the issue is argued also by theoretical background of examined issue from national and foreign authors, e.g. Bernstein (1961, In: Pape 2007); Doherty-Sneddon (2005); Hlebová, 2012; Hlebová, Ďord’ovičová, Palková, 2014, 2015; Hlebová, Ďord’ovičová, 2015; Hlebová, 2016a, 2016b; Hlebová, 2017a, 2017b, 2017c; Hrebeňárová, 2016; Horňák, 2001, 2005; Horňák, Kollárová, Matuška, 2016; Klein, 2008; Koch (1976, In: Lechta, 2008); Kovalč́́ková, 2009, 2010, 2015a, 2015b, 2015c, 2017; Liptáková a kol., 2011; 
Liptáková, 2012; Mertin, Krejčová, 2016; Metelková Svobodová, Švrčková, 2010; Kende, Neményi, 2006; Kožárová, 2017; Lidz, Jesen, Krejčová, 2014; Pokorná, 2007, 2010; Portik, 2003; Rosinský a kol., 2009; Sindelarova, 1996, 2008; Šilonová, Klein, 2015; Valenta, Michalík, Lečbych, 2012; Vágnerová, 1997, 2002; Zelina, 1996; Zelina a kol., 2002; Zezulková, 2011, Žovinec, 2014a, 2014b, who have dealt with issue of improvement of school achievement of socially disadvantaged pupils from marginalized Romany communities, also through stimulation of their cognitive functions, as well as on basis of own research conducted in the process of improvement of reading competence level in socially disadvantaged pupils in younger school age (Vojteková, 2018).

Already in the process of communicative competence development in weak pupils, Doherty-Sneddon (2005) considers as the best approach non-verbal communication, what he arguments with statement that if we want to communicate with pupils effectively, we have understand them enough without words. According to mentioned author, this is an assumption for acquiring of verbal communication. According to Hlebová and Ďord'ovičová (2015) reading competence is related to communicative competence development, thus the mastering of right technique and way of reading, as well as the reading comprehension. During the Slovak language and literature lessons while working with literary text we can create for the pupils an appropriate communicative situation supporting their communicative and reading competence, what we consider to be a source status quo in the context of improving their school success also in other lessons and disciplines. In this regard in the study we present proposal for drafting and implementation of cognitive stimulation programme through the methodology of dynamic testing according to diagnostic measure ACFS (Application of Cognitive Functions Scale, Czech version, Lidz, Jepsen, Krejčová, 2014, for working with the adaption of selected literary text from Hivešová-Šilanová Children of the Sun (2015).

In the process of drafting stimulation programme for cognitive functions development (sorting, sequential auditory memory, short-term visual memory, addition of sequential patterns, perspective taking, and verbal planning) we propose to follow the methodology of dynamic assessment of cognitive functions in children ACFS-cz (Lidz, Jepsen, Krejčová, 2014), which is suitable for children in preschool and younger school age. Its importance is also in the fact that a teach might through questions (intervention) in a process of solving tasks uncover the potential of learning skills of pupils and, at the same time, teach the pupils how to learn. In the stimulation programme we follow the assumption that the cognitive skills of pupils are not unchangeable, and therefore we have focused on the thinking processes of pupils (the way a pupil achieved performance, what kind of intervention he/she required). Thus during the stimulation we create for pupils enriching environment, we use questions and tasks, which might improve their thinking and also respect individual approach to each pupil (according to recommendations of authors Metin, Krejčová et al., 2016).

When creating a proposal of stimulation programme, we recommend to work with literary text, in our case it was folder-book Children of the Sun - adaptation of the Romany folk-tale from D. Hivešová-Šilanová (2014), from which we can use a word and a picture (text and illustration) in the intervention. Furthermore, we recommend, if possible, provide each pupil with own book (folder-book) and sufficient amount of didactic tools for working on different tasks. In the implementation of stimulation programme we work with each pupil individually, we motivate him all the time, praise his effort, and reinforce him to better achievement. Our aim should be to make a pupil experience positive emotions and success form achieved results during working on different tasks from stimulation programme.

We incorporated the stimulation programme for development of cognitive functions into the scheme, which was designed according to different phases of teaching unit. It consists of organisational part with objectives, tools, methods, and forms of stimulation; stimulation part - consists of 6 dimensions of cognitive functions (sorting, sequential auditory memory, short-term visual memory, addition of sequential patterns, perspective taking, and verbal planning), while each of these contains 5 tasks for solving with interventional options for a pupil; and final part-summary in form of recommended final communication with a pupil. Stimulation programme includes also forms for intervention evaluation and behaviour of a pupil, which are part of the diagnostic measure ACFS-cz (2014) and which we recommend to use within the implementation of stimulation programme in special-educational practice (individual stimulation of each cognitive dimension should take maximum of 45 minutes).

\section{Stimulation Programme}

\subsection{Stimulation Programme: Sorting}

Tasks for a pupil for improving his cognitive function - sorting require certain extent of abstraction, an ability to identify partial characteristics of selected suggestions, their mutual comparison, systematic and complex 
procession of selected suggestions (ACFS-cz, Lidz, Jepsen, Krejčová, 2014).

Different interventional tasks enhance a pupil to sort various objects and thus improve his cognitive skills. Main objective of cognitive stimulation is to teach a pupil to categorise objects according to specific characteristic and to be able to name them. Implementation of the stimulation programme leads to understanding of sorting objects into groups according to concrete characteristics - firstly according to shape (group of letters, group of numbers), then according to colours (group of objects of blue colour, red colour, yellow colour, green colour), subsequently according to pictures from the book (group of pictures with human figures, group of pictures with images of nature, group of pictures illustrating seasons autumn and winter, group of pictures with the Sun); the final task directs to improvement of a pupil's ability to sort out from the letters those, with which he can put together the title of book Children of the Sun.

The assignments are focused on the development of communicative and reading competence of pupils technique and way of reading, with using identification of different letters of alphabet and creating nomenclature names naming specific group of subjects. From the proposal of stimulation programme for sorting we have chosen as an example two tasks for a pupil.

Objectives:

a) Cognitive (informative): Categorise subjects according to specific characteristic and name them.

b) Affective (formative): Express prosocial relations during the work on assignments.

c) Psycho-motoric (sensual-movement): Engage sensory perception and gross and fine motor skills into selected activity.

Tools: set of colourful letters and numbers, folder-book Children of the Sun

Methods: questions and answers method, analysis, synthesis, comparison, generalisation, multiple repeating method

Forms of work: individual

Methodology:

Organisational and motivational part:

Preparation of tools.

Motivational discussion with a pupil.

Familiarizing a pupil with listening and reading Romany folk-tale Children of the Sun.

Stimulation part:

$1^{\text {st }}$ assignment: Name these subjects. Categorise them into groups.

(Teacher puts in front of a pupil set of colourful paper letters and numbers. A pupil is supposed to name these subjects, and categorise them into groups according to specific characteristics - e.g. group of alphabet letters, group of numbers, group according to a colour, etc.).

1. a) Name the subjects.

What do they mean?

Categorise the subjects into groups according to what they mean.

b) Name the subjects.

What do they mean?

I will help you: These are the letters from alphabet. Repeat that.

Categorise other subjects into groups according to what they mean.

c) Name the subjects.

We already know that these are the alphabet letters.

What objects are there yet?

Categorise the subjects into groups according to what they mean.

One group will consist of letters. What will be in the other group?

d) Name the objects. These are letters and these are numbers. Repeat it. 
Categorise letters and numbers into groups.

e) Name the objects. These are letters and these are numbers. Repeat it.

Create the group of letters.

Create the group of numbers.

Name, what these group mean: This is the group of letters. Repeat it.

This is the group of numbers. Repeat it.

$2^{\text {nd }}$ assignment: Sort out from alphabet the letters with the book title.

(Teacher puts in front of a pupil alphabet letters. A pupil is supposed to sort out the letters, with which he can create the title of book CHILDREN OF THE SUN. A pupil can help with the title page of the book).

2. a) Look at the letters.

We have worked with them already.

Put the letters in front of you so you could see them and read them (to a line).

b) Look at the letters once more.

The book we are going to read today is called CHILDREN OF THE SUN.

Look at the book.

Pick from alphabet the letters in the book title.

Tell me, what letters you need to search for?

c) Look at the letters once more.

I will help you: Read the first letter from the book title.

Search for the first letter $-C$.

Add to the title missing letters.

d) Look at the letters once more.

I will help you: Search for the missing letters - I, L, D, R, E, N, O, F, T, H, E, S, U, N.

Put the letters together so you could write the book title.

e) Look at the letters you have picked.

You did it correctly.

Put the letters together so you could write the book title CHILDREN OF THE SUN.

You can help with the title on the book cover.

Read the book title you have created from the alphabet letters.

Summary: Recommended final communication with a pupil

Look, you did very well. You have learnt to categorise objects into groups. You can see that objects might be categorised into groups according to specific characteristics. Firstly we had to recognise the shape of objects these were letters and numbers. Out of that we have created group of numbers and group of letters. Then we recognised colours of letters and numbers. We created groups of the same colour - group of blue colour, group of red colour, group of yellow colour, and group of green colour. Then we looked at the pictures in the book Children of the Sun. Out of the pictures we have created groups - group of pictures with human protagonists, group of pictures form nature, group of pictures with sceneries from seasons-autumn and winter, and group of pictures with Sun. And then we sorted out from the alphabet letters those, with which we could create the book title Children of the Sun. Finally you have repeated your mathematics. You learnt to create groups of words according to the number of letters.

Now you will know to categorise objects into groups on your own.

\subsection{Stimulation Programme: Sequential Auditory Memory}

Tasks for a pupil for improving cognitive function - sequential auditory memory require concentration of his attention for listening to a story (auditory perception) and an ability to remember different sequences of a story in three parts - introduction, core, conclusion (ACFS-cz, Lidz, Jepsen, Krejčová, 2014). 
Different interventional tasks enhance a pupil to focus on listening to the folk-tale record and subsequent reproduction of listened story. Main objective of cognitive stimulation is to teach a pupil to remember the story in parts based on its listening and be able to reproduce it. Implementation of the stimulation programme directs to improvement of auditory perception - firstly with creating words from right syllables that occurred in the story (with this task we followed the cognitive function - sorting); then with correct sorting out of the words that occurred in the story; with reproducing the story in parts (introduction, core, conclusion) based on its listening; the final task leads to improvement of a pupil's ability to reproduce whole story briefly and individually.

The assignments are focused on the development of communicative and reading competence of pupils technique and way of reading, reading comprehension, with using auditory analysis and synthesis of a word, with an ability to speak in the reproduction of different parts of the listened story, and finally the whole story in its causal and logical continuity of the text. . From the proposal of stimulation programme for sequential auditory memory we have chosen as an example two assignments for a pupil.

Objectives:

a) Cognitive (informative): Remember the story by parts, based on listening and be able to reproduce it.

b) Affective (formative): Express prosocial relations during the work on assignments.

c) Psycho-motoric (sensual-movement): Engage sensory perception and gross and fine motor skills into selected activity.

Tools: CD player, CD record, folder-book Children of the Sun, pictures from the book, cards with syllables from words

Methods: direct discussion, questions and answers method, analysis, synthesis, multisensory mediation method, multiple repetition method

Forms of work: individual

Methodology:

Organisational and motivational part:

Preparation of tools.

Motivational discussion with a pupil.

Familiarizing a pupil with listening to the Romany folk-tale Children of the Sun.

Stimulation part:

$1^{\text {st }}$ assignment: Listen to the story carefully. Put the pictures in order according to the story.

(Teacher uses CD record from the book for listening to the story of Children of the Sun. during the listening in sequences - introduction, core, conclusion, a pupil follows carefully the pictures in book Children of the Sun. A pupil is supposed to create a picture wrap of the story - from the pictures according to listened story).

1. a) Listen carefully to the first part of the story. (CD record, pp. 3-5)

Put the pictures in order according to listened story.

aa) Listen carefully to the story once more. (CD record, pp. 3-5)

Look at the pictures in the book.

Put the pictures in order according to the story.

b) Listen carefully, how the story continues. (CD record, pp. 6-8)

Put the pictures in order according to the story.

bb) Listen carefully once more. (CD record, pp. 6-8)

Look at the pictures in the book.

Put the pictures in order according to the story.

c) Listen carefully to the story further. (CD record, pp. 9-11)

Put the pictures in order according to the story.

cc) Listen carefully to the story once more. (CD record, pp. 9-11)

Look at the pictures in the book. 
Put the pictures in order according to the story.

d) Listen carefully to the story further. (CD record, pp. 12 - 13)

Put the pictures in order according to the story.

dd) Listen carefully once more. (CD record, pp. 12 - 13)

Look at the pictures in the book.

Put the pictures in order according to the story.

e) Listen carefully, how the story ends. (CD record, pp. 14-15)

Put the pictures in order according to the story.

ee) Listen carefully once more. (CD record, pp. $14-15$ )

Look at the pictures in the book.

Put the pictures in order according to the story.

$2^{\text {nd }}$ assignment: Listen to the story. Add the correct word to text.

(Teacher instructs a pupil to listen carefully to the story. A pupil is supposed to recollect the story in his memory and add correctly the missing word).

2. a) Listen to me carefully.

I will read you step by step the story that you know already.

When I will make a break, you will add the missing word. (reading on the p. 3)

Add what is missing here... (houses, horses)

I will help you: Where did the Roma people live? Did they have their own place to live? (houses)

I will help you: What animals did drag their wains? (horses)

b) Listen carefully.

I will read the story further.

When I will make a break, you will add the missing word. (reading on the p. 4)

Add what is missing here... (warmth, winter, heat up)

I will help you: How do we feel in a summer, when the Sun is shining? Are we warm or cold?

I will help you: What do we need to, when we are cold? (warm up, heat up)

c) Listen carefully.

I will read the story further.

When I will make a break, you will add the missing word. (reading on the p. 5)

Add what is missing here... (Lavutaris, Sun, violin)

I will help you: What is the name of boy in the story? (Lavutaris)

I will help you: Whom Lavutaris went to search? (Sun)

I will help you: What did Lavutaris take with him on his way to the Sun? (violin)

d) Listen carefully.

I will read the story further.

When I will make a break, you will add the missing word. (reading on the p. 10)

Add what is missing here... (Lavutaris, violin, song)

I will help you: Who went to a journey to the Sun? (Lavutaris)

I will help you: What did he take with him to his journey to the Sun? (violin)

I will help you: What did Lavutaris play on his violin? (song)

e) Listen to me carefully.

I will read the story till the end.

When I will make a break, you will add the missing word. (reading on the p. 15)

Add what is missing here... (happiness)

I will help you: What did Lavutaris feel, when he found out that the Sun likes Roma people? How is it called, what every Roma desires? (happiness)

Summary: Recommended final communication with a pupil

You did really well. You learnt to remember whole story. Firstly you helped with the pictures from the book, which you put in order as you listen to the story. You have listened to the story in order to learn how to make the words from syllables and then the sentences from words, which you heard in the story. You remembered the story really precisely, as you could find the words, with which the story continued, but also the words, which did not belong to the story. 
Now you know that you can easily remember whole story by careful listening.

\subsection{Stimulation Programme: Short-Term Visual Memory}

Tasks for a pupil for improvement of cognitive function - short-term visual memory require remembering and recollecting of information, which pupil perceived with his senses (hearing and sight). It is development of ability called visual mechanic memory of a pupil (ACFS-cz, Lidz, Jepsen, Krejčová, 2014).

Different interventional tasks enhance a pupil to remember, hold and recollect from his memory the listened story with visual perception. Main objective of cognitive stimulation is to teach a pupil to remember and reproduce listened story with exercising his visual mechanical memory. Implementation of the stimulation programme directs to improvement of visual perception - firstly with listening to the story (with this task we followed the cognitive function - sequential auditory memory) and simultaneously with reading illustrations in the book; then with sorting out the illustrations that are not related to the story (with this task we followed the cognitive function - sorting), further with creating illustrated synopsis of the story (from the pictures in the book), and finally with reproducing the story in parts with using illustration for it; the final task directs to detailed reproduction of whole story individually with the illustrated synopsis.

The assignments are focused on the development of communicative and reading competence of pupils technique and way of reading, reading comprehension, with applying auditory and visual perception in reading the book, comparison of word and image, reading the illustrations - reproduction of the story in parts, and finally the reproduction of whole story in its causal and logical continuity of the text. From the proposal of stimulation programme for short-term visual memory we have chosen as an example two assignments for a pupil.

Objectives:

a) Cognitive (informative): Practice visual and auditory memory.

b) Affective (formative): Express prosocial relations during the work on assignments.

c) Psycho-motoric (sensual-movement): Engage sensory perception and gross and fine motor skills into selected activity.

Tools: folder-book Children of the Sun, pictures from the book

Methods: questions and answers method, analysis, synthesis, comparison, generalisation, multiple repetition method

Forms of work: individual

Methodology:

Organisational and motivational part:

Preparation of tools.

Motivational discussion with a pupil.

Familiarizing a pupil with listening and reading the Romany folk-tale Children of the Sun.

Stimulation part:

$1^{\text {st }}$ assignment: Listen to the story a read it yourself. Moreover, look at the pictures.

(Teacher uses the CD record Children of the Sun for reading the story by a pupil. He enables pupil to listen and at the same time to read the story with narrator himself. After reading the story, he carefully looks at the picture in book Children of the Sun. A pupil is supposed to create a picture wrap of the story - from the pictures in book, and retell the story according to them).

Put the pictures in order according to the story. Tell me the story yourself.

1. a) Read the story with narrator. (CD record on the pp. 3 -5)

Take a good look at the pictures.

Tell me, what you can see at the pictures.

a) Pick the pictures that you have read already.

Tell me the story according to the pictures.

b) Read the story with narrator further. (CD record on the pp. 6-8)

Take a good look at the pictures.

Tell me, what you can see at the pictures.

bb) Pick more pictures that you have read already.

Tell me the story according to the pictures. 
c) Read the story with narrator further. (CD record on the pp. 9-11)

Take a good look at the pictures.

Tell me, what you can see at the pictures.

cc) Pick some more pictures that you have read already.

Tell me the story according to the pictures.

d) Read the story with narrator further. (CD record on the pp. 12-13)

Take a good look at the pictures.

Tell me, what you can see at the pictures.

dd) Pick even more pictures that you have read already.

Tell me the story according to the pictures.

e) Read the story with narrator till the end. (CD record on the pp. 14-15)

Take a good look at the pictures.

Tell me, what you can see at the pictures.

ee) Pick the pictures that you have read so far..

Tell me the story according to the pictures.

f) Tell me whole story yourself.

Look at the pictures.

Tell me whole story yourself.

$2^{\text {nd }}$ assignment: Tell me, which picture is missing in the story.

(Teacher asks a pupil o have a look at the pictures from the book Children of the Sun once more. Afterwards, a pupil covers his eyes with palms, meanwhile a teacher removes from the picture wrap two pictures (e.g. picture from pp. 9, 13). A pupil is supposed to identify, which picture is missing and what as on the picture/what situation the picture expressed).

2. a) Take a good look at the pictures.

Put them in order as the story followed.

You retold the story very well.

Now cover your eyes with your palms.

And now look at the pictures.

Tell me, which picture is missing. (picture on the p. 4)

What situation is expressed at the picture?

a) I will help you: Remember, why Lavutaris decided to find the Sun.

Tell me, which picture is missing.

What situation is expressed at the picture?

b) Take a good look at the pictures.

Put them in order as the story followed.

Now cover your eyes with your palms.

And now look at the pictures again.

Tell me, which picture is missing. (picture on the p. 8)

What situation is expressed at the picture?

bb) I will help you: Remember, whom Lavutaris met on his journey to the Sun.

Tell me, which picture is missing.

What situation is expressed at the picture?

c) Take a good look at the pictures. 
Put them in order as the story followed.

Now cover your eyes with your palms.

And now look at the pictures again.

Tell me, which picture is missing. (picture on the p. 9)

What situation is expressed at the picture?

cc) I will help you: Remember, was Lavutaris sad, when he could not find the Sun.

Tell me, which picture is missing.

What situation is expressed at the picture?

d) Take a good look at the pictures.

Put them in order as the story followed.

Now cover your eyes with your palms.

And now look at the pictures again.

Tell me, which picture is missing. (picture on the p. 11)

What situation is expressed at the picture?

dd) I will help you: Remember, if Lavutaris found the Sun.

Tell me, which picture is missing.

What situation is expressed at the picture?

e) Take a good look at the pictures.

Put them in order as the story followed.

Now cover your eyes with your palms.

And now look at the pictures again.

Tell me, which picture is missing. (picture on the p. 13)

What situation is expressed at the picture?

ee) I will help you: Remember, how Lavutaris felt, when he was on his way back home.

Tell me, which picture is missing.

What situation is expressed at the picture?

Summary: Recommended final communication with a pupil

You learnt to remember whole story of the folk-tale. You helped with the story text, which you read with narrator and pictures that you followed in the book Children of the Sun. Then you put the pictures from book on the table as the story followed. Reading of the story and pictures helped you to remember the story so precisely that you were able to retell it on your own. You were even able to identify, which picture is missing in the story and which picture was spare one. You also learnt to compare the pictures and find their similarities, as well as the differences.

Now you will be able to retell whole story y pictures on your own.

\subsection{Stimulation Programme: Addition of Sequential Patterns}

Tasks for a pupil for improving cognitive function - supplementing sequential patterns require concentration of attention for realization of sequences (seriality). Task for a pupil is to register important characteristics of selected suggestions, realize more than one significant characteristic of the suggestions and to use already acquired skills from using terms: shape, colour, size (in stimulation the cognitive function of sorting) pupil (ACFS-cz, Lidz, Jepsen, Krejčová, 2014).

Different interventional task enhance a pupil to understand supplementing of objects into a set in right order according to specific rules and characteristics. Main objective of cognitive stimulation is to teach a pupil to understand the rules of supplementing objects according to sequential patterns. Implementation of the stimulation programme directs to improvement of visual perception and objects seriality - firstly with putting objects into a set according to specific rules; then with applying those rules in putting letters in a word; further with assigning right words into sentence according to those rules; and finally with right reading of created 
sentences; the final task leads to inventing new titles for the book. With the above tasks we followed already stimulated cognitive functions - sorting, sequential auditory memory, and short-term visual memory.

The assignments are focused on the development of communicative and reading competence of pupils technique and way of reading, reading comprehension, with applying auditory and visual perception in strengthening seriality in a word and a sentence according to the rules of logical continuity. From the proposal of stimulation programme for addition of sequential patterns we have chosen as an example two assignments for a pupil.

Objectives:

a) Cognitive (informative): Add objects according to indicated sequential patterns.

b) Affective (formative): Express prosocial relations during the work on assignments.

c) Psycho-motoric (sensual-movement): Engage sensory perception and gross and fine motor skills into selected activity.

Tools: set of colourful pictures of different size, shape, and colour; colourful sticks; folder-book Children of the Sun

Methods: questions and answers method, analysis, synthesis, comparison, generalisation, multiple repetition method

Forms of work: individual

Methodology:

Organisational and motivational part:

Preparation of tools.

Motivational discussion with a pupil.

Familiarizing a pupil with listening /reading the Romany folk-tale Children of the Sun.

Stimulation part:

$1^{\text {st }}$ assignment: Add the picture, which is missing.

(Teacher shows a pupil the set of colourful pictures. He takes out of them four pictures (e.g. flowers) of different size and colour, which he puts in a line. At the same time, he takes three more pictures, while only one of them is correct. Teachers asks a pupil to have a good look at the pictures in a line and out of the three pick the one, which should follow in the line. A pupil is supposed to pick one from three pictures of right colour and shape and add it to the line with pictures).

1. a) Look at the pictures in the line.

Have a good look at each picture.

Notice its shape and colour.

And now add the picture, which follows.

b) Look at the pictures again.

Look gradually at each picture.

Tell me, what is the colour and shape of each of them.

And now, pick one of these three, which follows.

c) Look at the pictures in the line once more.

Look at each picture carefully.

Tell me, what is their shape and colour, and how they follow.

Out of these three pictures pick one, which should follow, in your opinion.

d) Look at the pictures in the line again.

Look at each picture carefully.

Repeat, what is their shape and colour, and how they follow.

And now look at three more pictures. 
Tell me, what their shape and colour is.

Out of these three pictures pick one, which should follow, in your opinion.

e) Look at the pictures in the line again.

Look at each picture carefully.

Repeat, what is their shape and colour, and how they follow.

Put in the line the first picture and tell me, whether this one follows.

Put in the line the second picture and tell me, whether this one follows.

Put in the line the third picture and tell me, whether this one follows.

Tell me, which picture of these three is the right one to follow.

$2^{\text {nd }}$ assignment: Create a story from the verses in the book we have read.

(Teacher attracts a pupil's attention to cut pieces of paper with a text line from the book Children of the Sun. Teacher asks a pupil to create a story as it was in the book out of the pieces of paper. A pupil is supposed to pick of the cut papers with text the right ones and put them together so they will represent the story from the book Children of the Sun).

2. a) Look carefully at all of the cut papers with the text from the Children of the Sun book.

Create a story from the verses in the book we have read.

b) Have a good look at all of the cut papers with the text from the Children of the Sun book.

I will help you: Remember, what part of the story they express.

Create a story from the verses in the book we have read.

c) Have a good look at all of the cut papers with the text from the Children of the Sun book.

Read quietly all the texts.

Remember, what part of the story they express.

Create a story from the verses in the book we have read.

d) Have a good look at all of the cut papers with the text from the Children of the Sun book.

Read aloud all the texts.

Remember, what part of the story they express.

Create a story from the verses in the book we have read.

e) Have a good look at all of the cut papers with the text from the Children of the Sun book.

Read aloud all the texts.

Skim through the book and find the page, where these texts are.

Look into the book and create a story from the verses in the book we have read.

Summary: Recommended final communication with a pupil

You just learnt that objects follow each other according to specific rules. Also, you learnt that similar rules might be applied in a language too. If you want to say or write a word, you have to put the letters in a words according to specific rules so others could understand you. Is the same, when you want to read some word or a sentence. Words in a sentence are also written according to specific rules, so we can understand them. We prove that, when you were reading the book Children of the Sun, and also when you were inventing new title for this book.

Now you know that words consists of syllables and vocals according to specific rules. When we want to speak, read, and write, we have to put the words into sentences according to some rules as well.

\subsection{Stimulation Programme: Perspective Taking}

Tasks for a pupil for improving cognitive function - perspective taking require from a pupil an ability to empathize with emotional reactivity and thinking of another person, ability to think, whether another person can react to someone's instructions. The emphasis is given particularly on verbal and non-verbal expressions of a pupil, with which he is trying to instruct another person in work, what can manifest his ability to think about another person. During the intervention we improve metacognitive processes of pupils focused on the perception of selected children's picture book (ACFS-cz, Lidz, Jepsen, Krejčová, 2014). 
Different interventional tasks enhance a pupil to empathise into a role of another person and support improvement of the communicative skill - speaking. Main objective of cognitive stimulation is to teach a pupil to empathise into emotional reactivity and thinking of another person, also to be able to instruct that person in a concrete situation. Implementation of the stimulation programme directs to improvement of a pupil's ability to understand emotional reactivity of someone else, to be able to predict his behaviour and teach him to instruct someone in a concrete situation - firstly with changing of roles of a pupil and a teacher (pupil in a position of teacher); subsequently with the intervention for a pupil, how he should instruct a teacher; and finally with re-exchange of the roles of pupil and teacher. With the tasks we followed already stimulated cognitive functions - sorting, sequential auditory memory, short-term visual memory, and addition of sequential patterns.

The assignments are focused on the development of communicative and reading competence of pupils technique and way of reading, reading comprehension, with applying auditory and visual perception, as well as the speaking ability in changing the roles of pupil and teacher - a pupil in a teacher position learns to induct a situation how to proceed in learning something new, while he enhances also his own cognitive functions in the process of mastering reading, writing, and drawing. From the proposal of stimulation programme for perspective taking we have chosen as an example two assignments for a pupil.

Objectives:

a) Cognitive (informative): Empathise with another person, instruct another person in work with verbal and non-verbal expressions.

b) Affective (formative): Express prosocial relations during the work on assignments.

c) Psycho-motoric (sensual-movement): Engage sensory perception and gross and fine motor skills into selected activity.

Tools: folder-book Children of the Sun; pictures from the book; paper; colour-box

Methods: induction, deduction, analysis, synthesis, comparison, generalisation, multiple repetition method

Forms of work: individual

Methodology:

Organisational and motivational part:

Preparation of tools.

Motivational discussion with a pupil.

Familiarizing a pupil with listening /reading the Romany folk-tale Children of the Sun.

Stimulation part:

$1^{\text {st }}$ assignment: Teach me, how I can read the book myself.

(Teacher instruct a pupil, how to proceed when he starts to read a book. Then he tells a pupil to switch the roles for a while - a pupil will be a teacher and a teacher will be in a role of pupil. A pupil-teacher is supposed to teach a teacher-pupil, how to read a book. A pupil-teacher during the instruction of a teacher-pupil use verbal and non-verbal expressions. Teacher provides a pupil with intervention according to following steps, so a pupil is able to teach someone else to read a book).

1. a) Now I will teach you, how you can read a book.

Firstly, take the book into your hands and pet it.

Tell me, how is the book when you touch it (is it pleasant to touch/awkward, smooth/rough, warm/cold).

b) Now, open the book at any page and smell it.

Tell me, what kind of smell does it have? (is it pleasant/ awkward?)

What does it remind you? Why is it so?

c) And now have a look at the cover page of the book.

What colour is the book's cover page?

What can you see at the cover?

What is the picture there?

What colour is the Sun? 
What is the Sun doing?

Why is it smiling?

What is the Sun holding in his hands?

Why is the Sun holding in one hand a violin and in the other one a little heart?

What is on the picture behind the Sun?

What colour is the sky?

Why there are clouds on the sky?

Look at the colour of the sky today. Are there any clouds?

What does it mean, when they are cloud on the sky?

What do you think, what will be the book about?

What is written on the book with capital letters?

Read it aloud. This is the book title.

What does the book title express?

What do you think, what will be the book about according to its title?

Why there is written the title in another languages also?

Can you read them?

Do you understand, what you have read?

Why do not you understand?

d) And now have a look at the back page of the book.

What colour is the back page?

What can you see at the back page?

Why are there these pictures?

Who is on these pictures?

What can you see left down? What do these pictures illustrate?

Do you know these flags? Do you know, to which country each of them belongs?

e) And now look through whole book.

What can you see in the book?

What are the pictures?

Tell me, what the pictures illustrate?

Can you tell me, what will be the story in the book about?

Are the pictures sad or happy?

Why do think that they are happy or sad?

And is there anything else you have noticed in the book, in addition to the pictures?

Can you tell in what languages are the texts in the book?

Do you know these languages?

In what language do we learn to read, write, and speak?

Can you say anything in any other language?

Say something in the Romany language,

And now say the same in the Slovak.

Now you can read the book page by page and also look at the pictures at the same time.

After reading the book we can talk, how you liked it.

f) Now teach me, how I can read the book on my own. 
$2^{\text {nd }}$ assignment: Teach me, how to draw a picture.

(Teacher instructs a pupil, how to proceed, when he wants to draw a picture from the book. Then he tells a pupil that they will switch the roles again - pupil will become a teacher and vice-versa. A pupil-teacher is supposed to teach a teacher-pupil, how to draw a picture. A pupil-teacher is allowed in the instructing of a teacher-pupil to use as verbal as well as non-verbal instructions. Teacher provides a pupil with intervention so a pupil knows in detail how to draw a picture).

2. a) Now I will teach you, how to draw this picture. (p. 1)

But firstly I will tell you something about the picture.

Objects that you are going to draw as first you can see on the sky.

What can we see on the sky? What is the colour of sun? What is the colour of clouds?

What are we doing, when it starts raining? When can we see the snow falling from the sky?

b) Now we will try to draw the first thing on the picture.

Take a pencil and a draw exactly according to my instructions.

Firstly, we pay attention to correct orientation on the paper (up, down, right, left).

c) Now we will try to draw the second thing on the picture.

Take a pencil and a draw exactly according to my instructions.

Secondly, we pay attention to correct shape of an object (round, angled, square, rectangle, triangle, and circle).

d) Now we will try to draw the third thing on the picture.

Take a pencil and a draw exactly according to my instructions.

Thirdly, we pay attention to correct size of an object on the paper (big, small).

e) Step by step we will draw all the pictures on the paper.

Finally, we pay attention to orientation, shape and size of the objects spaced on the paper.

Now, you teach me, how I can draw a picture myself.

Summary: Recommended communication with a pupil.

You learnt how to read a book. And you also learnt that we can read a book not only with our eyes, but also with our hands or smell. Moreover, you learnt that we can read not only words and sentences, but also pictures. You found out that we can learn a lot from the pictures, for example what will be the story about. You learnt how to read a book correctly, and how to describe a picture. You managed to invent a short story based on specific words. And you learnt, how to draw a story according to specific words. And finally, you learnt, how to instruct your classmate, when he will want to read a book or draw a picture from the book himself.

Now you know, how interestingly the books could be read. You also know that the books are read from the beginning till the end page by page. If we would skip some pages, we would not understand the story.

\subsection{Stimulation Program: Verbal Planning}

Tasks for pupils for improvement of cognitive function - verbal planning require from a pupil an ability to describe verbally sequence of steps in an activity. In a certain way it corresponds with the cognitive function of supplementing sequential patterns, because the common denominator is seriality - ordering the steps in a certain sequence (e.g. in reproducing a story it is introduction, core and conclusion) (ACFS-cz, Lidz, Jepsen, Krejčová, 2014).

Different interventional tasks enhance a pupil to verbal communication. Main objective of cognitive stimulation is to teach a pupil to describe with own words the sequence of steps in inventing own story. Implementation of the stimulation programme directs to improvement of a pupil's ability to understand certain rules in inventing own story in causal and logical continuity of a text corresponding with introduction, core, and conclusion. Firstly a pupil reads the story on his own, while reading he comments illustrations in the book; then he reproduces the story in causal and logic continuity of the text (introduction, core, and conclusion); furthermore he invents his own story (or he diversifies original story and title of the book according to his own fantasy) in causal and logic continuity of the text (introduction, core, and conclusion); and finally he retells own story (with own illustrations also) in his own book about Lavutaris; in the final part a pupil is able to recognize the differences between his 
own story and the original one. With the tasks we followed already stimulated cognitive functions - sorting, sequential auditory memory, short-term visual memory, addition of sequential patterns, and perspective taking.

The assignments are focused on the development of communicative and reading competence of pupils technique and way of reading, reading comprehension, with applying auditory and visual perception, as well as the speaking ability and creative thinking in inventing own story - book about Lavutaris (including its title and illustrations) in causal and logic continuity of the text (introduction, core, and conclusion), and thus we stimulate cognitive functions of pupils in the process of mastering reading, writing, and drawing. From the proposal of stimulation programme for verbal planning we have chosen as an example two assignments for a pupil.

Objectives:

a) Cognitive (informative): Describe with words sequence of steps in selected specific activity.

b) Affective (formative): Express prosocial relations during the work on assignments.

c) Psycho-motoric (sensual-movement): Engage sensory perception and gross and fine motor skills into selected activity.

Tools: folder-book Children of the Sun; paper; colour-box; tear tape; coloured paper; glue; scissors

Methods: questions and answers method, induction, deduction, analysis, synthesis, comparison, generalisation, multiple repetition method

Forms of work: individual

Methodology:

Organisational and motivational part:

Preparation of tools.

Motivational discussion with a pupil.

Familiarizing a pupil with reading the Romany folk-tale Children of the Sun.

Stimulation part:

$1^{\text {st }}$ assignment: Tell me, how the story could continue.

(Teacher asks a pupil to read the story from book Children of the Sun. In specific selected parts of the text (sequence form the introduction with knot, overcoming the barriers, and conclusion - pp. 5, 9, 11, 15) tells a pupil to stop. Then teacher asks a pupil to think how the story could continue. A pupil is supposed to create a story, with his own fantasy, in selected parts of the text).

1. a) Tell me, how the story could continue.

Tell me, what we know so far from the story.

What happened in the moment you stopped reading?

"Lavutaris grabbed his violin and left quickly to find the Sun..."

What could happen to Lavutaris?

Where could Lavutaris go?

Whom could Lavutaris ask for help?

b) Tell me, how the story could continue.

Tell me, what we know so far from the story.

What happened in the moment you stopped reading?

"Lavutaris was very sad and tired and almost crying."

Why was Lavutaris sad and almost crying?

What would you advise him?

Where he could find the Sun?

Whom he could ask for help?

How could you help him?

c) Tell me, how the story could continue. 
Tell me, what we know so far from the story.

What happened in the moment you stopped reading?

"The Sun heard Lavutaris and parted the heavy snow clouds, melted the ice, and stopped the wind."

What could happen in the story next?

How could the Sun behave towards Lavutaris?

What could the Sun tell Lavutaris?

Could the Sun help Lavutaris?

What could the Sun advise Lavutaris?

What would you advise Lavutaris?

d) Tell me, how the story could continue.

Tell me, what we know so far from the story.

What happened in the moment you stopped reading?

"Lavutaris with the singing in his heart ran down to the Roma camp."

Was Lavutaris happy, when he was coming back home?

Why he was so happy?

What nice and good could happen to him in addition to all the above mentioned?

How could others welcome Lavutaris in the Roma camp?

e) Did you like the story you have read?

How would you like the story more?

Tell me, what would you like to change in it?

Why do you want to change it?

$2^{\text {nd }}$ assignment: Tell me, how you can create your own book about Lavutaris.

(Teacher asks a pupil to create his own book based on the invented story about Lavutaris. For that he can also create new pictures and new book title. A pupil is supposed to create own book about Lavutaris - write the story, draw the pictures, and invent new title).

2. a) Create your own book about Lavutaris.

What do you need for creating own book?

What tools you have to prepare?

What do you need them for?

Where will you use them?

b) How many pages will your book have?

How many papers you will prepare?

On which part of the paper you will place the text and where a picture will be drawn?

Tell me, why did you decided so?

c) Firstly, write the text of your story in rough.

Do you know, why you do not write it straight to the book?

d) Now draw a picture next to the text.

Try to draw such picture that will illustrate the text.

Count how many pages of text you created for you book.

Tell me, how many pictures you need to draw.

e) Put the pages with text of your story in the right order.

Start with introduction. How the story started?

Then continue with the pages hat represent continuation of the story. 
Finish your book with the page, where the story ends.

How you will bind the pages into a book.

What will you use for the book cover?

What will you write and draw on the book cover?

What will you write and draw on the back page?

Tell me the title of the book you have invented?

f) Tell me about your new book and the story about Lavutaris.

What differs your story from the original story in the book Children of the Sun?

What did you change in your story about Lavutaris?

Summary: Recommended final communication with a pupil.

You invented nice story about Lavutaris. You learnt that you can read a story from book or invent new one. You also learnt that every story needs to have introduction, continuation, and conclusion. You found out how easily you can invent own stories and share them with others. Moreover, you learnt that you can your own story write down and draw some pictures for it. And finally, you learnt to create own book. No you can think about the differences of your book and the book Children of the Sun.

Now you know how interestingly the new stories might be invented and how you can create your own book. And then you can show it to your classmates.

Part of the stimulation programme proposal for development of cognitive functions of the pupils should be also an observation of their behaviours during the intervention, where we can use structured behaviour's observation based on recommended methodology of ACFS-cz (2014). The structured observation form contains 7 items focused on the observation of a pupil in following areas - self-regulation (regulates and/or supresses impulsive reaction - we observe, whether a pupil is able to concentrate on a task solving; whether he behaves impulsively; whether he can supress impulsive behaviours; and whether he requires intervention form a teacher while concentration on an assignment); endurance (when completing an assignment - we observe, whether a pupil resigns during the completing; whether he complains on difficulty of assignment; whether he completes assignment on his own or needs an intervention for teacher); tolerance and frustration (continues in assignment despite that the difficulty level might be demotivating - we observe, whether a pupil is able to calm down when he is frustrated from a task completing; whether he calms down only for a while; whether he does not calm down at all; or whether he requires intervention form teacher to calm down); flexibility (tries alternative solutions or corrects himself when completing and assignment - we observe, whether a pupil invents alternative solutions; whether he wants to find another way of solving an assignment; whether he follows original process of solution and is not able to make any change; or whether he requires intervention from a teacher), motivation (significant reaction or interest in assignment or material - we observe, whether a pupil reacts on assignment and tools enthusiastically, neutrally; whether he shows interest in completing an assignment or work with tools; whether he shows up that he does not like an assignment; or whether he requires intervention from a teacher more often ), interaction (interest in mutual social interaction - we observe, whether a pupil joins communication with a teacher; whether he answers in dialogue very simply; whether he joins discussion or not; or whether he requires intervention from a teacher); response (interest in help from examiner during intervention - we observe, whether a pupil cooperates with teacher actively and willingly; whether he is passive; whether he tries to use new strategies in completing an assignment; whether he reacts to stimuli from a teacher; whether he wants to work on his own; or whether he requires intervention from a teacher). Based on the scaled behaviours observation of a pupil within the stimulation programme implementation and intervention in completing different assignments for development of cognitive functions, we might get a feedback about specified targets of stimulation fulfilment and information on effectiveness of proposed stimulation programme, which might be repeatedly modified according to individual skills and needs of a pupil.

\section{Conclusion}

When designing the study we based on the current issues of education of socially disadvantaged pupils from marginalised Roma communities in Slovakia, in who we can support development of their communicative and reading competence in literary Slovak language with stimulation of cognitive functions. Benefits of the stimulation programme proposal for cognitive functions development was recorded within conducted research (Vojteková, 2018), with which we supported development of reading competence in socially disadvantaged pupils with mild intellectual disabilities coming from marginalised Roma communities. After the stimulation 
programme implementation was recorded minimizing of the most frequent errors in the reading technique failure in length of phoneme, confusion in length of phoneme, omission of syllables, addition of syllables, failure in diacritic wedge, inappropriate pause in a sentence, incorrect intonation in middle of a sentence; in the way of reading - spells, fluent reading, groups of words with incorrect intonation; and in the reading comprehensionreproduces individually, reproduces by questions.

Moreover, in the implementation of stimulation programme in work with selected literary text Children of the Sun (Barfield, Hlebová, Cina, 2014) we might try to support in non-Roma pupils empathetic experiencing of negative feelings and emotions in Romany boy Lavutaris and understand them, and also support positive feelings and emotions and through that eliminate in their expressions prejudice and intolerant behaviours towards Romany pupils. Simultaneously, we can support self-confidence, self-identification with own ethnicity, and prosocial behaviours towards non-Roma classmates in pupils from marginalised Roma communities. Thus, in terms of school inclusion of socially disadvantaged pupils from marginalised Roma communities we can spontaneously implement principle of multicultural and emotional education, i.e. mutual understanding and acceptance of otherness.

Therefore, based on the mentioned above, we consider presented stimulation programme proposal for development of cognitive functions effective, and therefore we recommend it for current educational practice within inclusive education of socially disadvantaged pupils form marginalised Roma communities at elementary schools in Slovakia.

\section{Acknowledgements}

Study is the partial outcome of the research project $A P V V-15-0071$ Man with handicap in the literature for children and youth (2016 - 2020).

\section{References}

Barfield, S., Hlebová, B., \& Cina, S. (2015). Deti Slnka/Children of the Sun/Khameskere čhave. Prešov: Pedagogická fakulta Prešovskej univerzity v Prešove.

Doherty-Sneddon, G. (2005). Neverbální komunikace dètí. Praha: Portál.

Ďord’ovičová, J., Hlebová, B., \& Pálková, V. (2014). Čiastkové kognitívne funkce ovplyvňujúce spôsob čítania u žiakov s l'ahkým stupňom mentálneho postihnutia. In História, súčasnost' a perspektívy vzdelávania na Pedagogickej fakulte Prešovskej univerzity v Prešove. Zborník príspevkov z vedeckej konferencie s medzinárodnou účast'ou organizovanej Pedagogickou fakultou PU pri príležitosti 65. výročia založenia PF v Prešove. Prešov: PU PF. Retrieved http://moodledata.pf.unipo.sk/zborniky/Historia-sucasnost-a-perspektivy-vzdelavania-2014.pdf

Hlebová, B. (2012). Komplexný komunikačný, integrovaný prístup v edukácii žiakov s mentálnym postihnutím. In: Špeciálna pedagogika na Slovensku $v$ kontexte rokov 1967-2012. Zborník medzinárodnej vedeckej konferencie. Bratislava: IRIS.

Hlebová, B. (2016b). Otherness of Roma in Inclusive education of Roma pupils in Slovakia. In: International science index. International Journal of Social, Behavioral, Educational, Economic, Business and Industrial Engineering, 10(4), 1123-1128.

Hlebová, B. (2017a). Children Romany Literary Character with the Social Disadvantage in the Emotional Education. Asian Journal of Social Science Studies, 2(1), 92-102. https://doi.org/10.20849/ajsss.v2i1.114

Hlebová, B. (2017b, July). Children's literary protagonist with a social disadvantage in the inclusive education of pupils from Roma ethnic group in Slovakia. In EDULEARN 17 Proceedings 9th International Conference on Education and New Learning Technologies(3rd-5th, 8320-8331). SPAIN, Barcelona: IATED Academy. Retrieved from file:///E:EDULEARN17.html\#publication

Hlebová, B. et al. (2016a). Vybrané kapitoly zo špeciálnej didaktiky predmetov (pre učitelov žiakov s mentálnym postihnutím). Prešov: Vydavatel'stvo Prešovskej univerzity.

Hlebová, B., \& Ďord’ovičová, J. (2015a). Rozvíjanie komunikačnej a čitatel'skej kompetencie žiakov s l'ahkým stupňom mentálneho postihnutia v inklúzii. Prešov: Vydavatel'stvo Prešovskej univerzity.

Hlebová, B., \& Vojteková, G. (2017c). Dynamic Assessment (ACFS-cz) in the Context of Improving Reading Competence in Socially Disadvantaged Pupils with Mild Intellectual Disabilities. Štúdie zo špeciálnej pedagogiky/Studies in Special Education, 6(2), 9-44.

Hlebová, B., Ďord’ovičová, J., \& Pálková, V. (2015b). Kognitivna stimulácia čitatel'skej kompetencie žiakov s 
l'ahkým stupňom mentálneho postihnutia v školskej integrácii. Prešov: vydavatel'stvo Prešovskej univerzity.

Horňák, L. (2001). Prospechovo slabší žiak v škole. Prešov: Pedagogická fakulta Prešovskej univerzity.

Horňák, L. (2005). Rómsky žiak v škole. Prešov: Pedagogická fakulta Prešovskej univerzity.

Horňák, L., Kollárová, E., \& Matuška, O. (2016). História starostlivosti o l’udí s postihnutím a narušením v európskom kontexte. Prešov: Vydavatel'stvo Prešovskej univerzity.

Hrebeňárová, L. (2016). Edukácia osôb s viacnásobným postihnutím. Prešov: Vydavatel'stvo Prešovskej univerzity.

Klein, V. (2008). Multikultúrna výchova a Rómovia. Nitra: Univerzita Konštantína Filozofa.

Kovalčíková, I. (2010). Kognitívna stimulácia individuálnych edukačných potrieb žiaka zo sociálne znevýhodneného prostredia. Prešov: Prešovská univerzita v Prešove.

Kovalčíková, I. (2017). Kognitívna pedagogika 1. Kognitívne determinanty edukačného procesu. Hypotetické, deduktívne a inferenčné myslenie. Prešov: Vydavatel'stvo Prešovskej univerzity

Kovalčíková, I. et al. (2015a). Vzdelávaním pedagogických zamestnancov $k$ inklúzii marginalizovaných rómskych komunit. Národný projekt. Bratislava: Metodicko-pedagogické centrum. Retrieved June 8, 2017, from http://web.eduk.sk/ZES\%20MRK\%20I.pdf

Kovalčíková, I., \& Sternberg R. (2009). Kultúrna a kompetencie: Adaptívne schopnosti rómskych žiakov. Prešov: vydavatel'stvo Prešovskej univerzity v Prešove

Kovalčíková, I., Bobáková, M., Filičková, M., Ropovik, I., \& Slavkovská, M. (2015c.) Terminologické minimum kognitívnej edukácie. Prešov: Vydavatel'stvo Prešovskej univerzity.

Kovalčíková, I., Ropovik, I., Ferjenčík, J., Liptáková, L., Klimovič, M., Demko, M., ... Brajerčík, J. (2015b.) Diagnostika a stimulácia kognitívnych a exekutívnych funkcií žiaka v mladšom školskom veku. Prešov: Vydavatel'stvo Prešovskej univerzity.

Kožárová, J. (2017). Current trends in the education of children with attention deficit hyperactivity disorder for improving their reading competence. Science \& society: 4th international multidisciplinary scientific conference on social sciences and arts SGEM 2017: conference proceedings, 5, 89-96. Sofia: STEF92 Technology.

Lechta, V. (2008). Symptomatické poruchy řeci u dětí. Praha: Portál.

Lidz, C., Jepsen, R.H., \& Krejčová, L. (2014). Dynamické testování kognitívních funkcí u dětí ACFS (cz). Otrokovice: Propsyco.

Liptáková, L. (2012). Kognitívne aspekty vyučovania materinského jazyka v primárnej edukácii. Prešov: Pedagogická fakutla Prešovskej univerzity v Prešove.

Liptáková, L. et al. (2011). Integrovaná didaktika slovenského jazyka a literatúry v primárnom vzdelávaní. Prešov: PF PU v Prešove.

Mertin, V., Krejčová L. et al. (2016). Metody a postupy poznávání žáka: pedagogická diagnostika doplněné a aktualizované vydání. Praha: Wolters Kluwer ČR.

Metelková-Svobodová, R., \& Švrčková, M. (2010). Čtenářská gramotnost na 1. stupni ZŠ z pohledu vzdělávacího oboru český jazyk a literatura. Ostrava: Ostravská univerzita v Ostravě.

Pape, I. (2007). Jak pracovat s romskými žáky. Přiručka pro učitele a asistenty pedagogů. ČR: občanské sdružení Slovo 21.

Pokorná, V. (2007). Cvičení pro děti se specifickými poruchami učení: rozvoj vnímaní a poznávání. Praha: Portál.

Pokorná, V. (2010). Vývojové poruchy učení v dětství a dospělosti. Praha: Portál.

Portik, M. (2003). Determinanty edukácie rómskych žiakov. Prešov: PF PU.

Prined-Projekt inklúzivnej edukácie. (2014). Prešov: Metodicko-pedagogické centrum. Retrieved June 8, 2017, from http://www.prined.sk/o-projekte

Rosinský, R., Šramová, B., Klein, V., \& Vanková, K. (2009). Pedagogicko-psychologické a interkultúrne aspekty práce učitel’ov žiakov z odlišného sociokultúrneho prostredia. Nitra: Univerzita Konštantína Filozofa.

Šilonová, V., \& Klein, V. (2015). Edukácia sociálne znevýhodnených žiakov so špecifickými vývinovými poruchami učenia. Ružomberok: VERBUM-Vydavatel'stvo Katolíckej univerzity v Ružomberku. 
Sindelarová, B. (1996). Předcházíme poruchám učení: soubor cvičení pro děti v předl'kolním roce a v prvni třídě. Praha: Portál.

Sindelárová, B. (2008). Deficity čiastkových funkcií. Príručka porúch učenia a správania u detí a ich náprava. Bratislava: Psychodianostika.

Vágnerová, M. (1997). Psychologie problémového ditěte školního věku. Praha: UK.

Vágnerová, M. (2002). Kognitivví a sociální psychologie žáka základní školy. Praha: Univerzita Karlova v Praze.

Valenta, M., Michalík, J., Lečbych, M. et al. (2012). Mentální postižení v pedagogickém, psychologickém a sociálně-právním kontextu. Praha: Grada.

Vojteková, G. (2018). Čitatel’ská kompetencia sociálne znevýhodnených žiakov s l'ahkým mentálnym postihnutím a špeciálnopedagogická intervencia. Unpablished dissertation under the supervision of assoc.

Zelina, M. (1996). Výchova detí zo sociálne znevýhodneného prostredia. Výchova a vzdelávanie detí zo sociálne znevýhodneného prostredia: zbornik z medzinárodnej vedeckej konferencie, 13-19.

Zelina, M., Valachová, D., Kadlečíková, Z., \& Butašová, A. (2002). Vzdelávanie Rómov. Bratislava: Media Trade.

Zezulková, E. (2011). Jazyková a komunikativní kompetence dětí s mentálním postižením. Ostrava: Ostravská univerzita.

Žovinec, E. (2014a). Kognitívne a metakognitívne pristupy k dyslexii-edukácia a poradenstvo. Bratislava: IRIS.

Žovinec, E., Krejčová, L., \& Pospíšilová, Z. (2014b). Kognitívne a metakognitívne prístupy k dyslexii-edukácia a poradenstvo. Bratislava: IRIS.

\section{Copyrights}

Copyright for this article is retained by the author(s), with first publication rights granted to the journal.

This is an open-access article distributed under the terms and conditions of the Creative Commons Attribution license (http://creativecommons.org/licenses/by/4.0/). 